Оксана БУЦ,

orcid.org/0000-0002-5868-3612 аспірант кафедри теорії та методики фізичої культури і спорту Запорізького національного університету (Запоріжжя, Украӥна) butsoksana1012@gmail.com

\title{
КОМПОНЕНТИ ФОРМУВАННЯ ПРОФЕСІЙНОЇ КОМПЕТЕНТНОСТІ МАЙБУТНІХ МЕДИЧНИХ СЕСТЕР ДО РОБОТИ З ОСОБАМИ ГЕРОНТОЛОГІЧНОГО ВІКУ
}

\begin{abstract}
У статті обтрунтовано актуальність формування професійної компетентності майбутніх медичних сестер до роботи з особами геронтологічного віку. Визначено компонентний зміст формування професійної компетентності майбутніх медичних сестер до роботи з особами геронтологічного віку, а саме: особистісний, мотивачійний, прочесуальний і пізнавальний компоненти. Особистісний, розкрито як сукупність важливих для професійної діяльності медичної сестри особистісних якостей, необхідних для роботи з особливо вразливою категорією пацієнтів особами геронтологічного віку (таких як уміння керувати власними емочіяли, спостережливість, відповідальність, адекватна самооиінка, співпереживання, самокритичність, врівноваженість, доброзичливість, толерантність, емпатійність, самоконтроль, прагнення до самовдосконалення й самоосвіти). Мотиваційний визначено як сукупність ціннісних орієнтацій, моральних установок і сочіальних очікувань, емоційно-вольовий комплекс, необхідний для роботи з особами геронтологічного віку. Проиесуальний виокремлено як комплекс фахових умінь, щзо дозволяють здійснювати професійну діяльність у роботі з особами геронтологічного віку. Пізнавальний розкривається як наявність професійних медичних знань та умінь у роботі з особами геронтологічного віку та здатність застосовувати їх; уміння вчасно, якісно та всебічно аналізувати, класифікувати і систематизувати професійні знання з геронтології, зокрема особливості профілактики й лікування у літньому віиі, герогігієна, зосереджена на питаннях загальної та спечіальної гігієни осіб літнього віку, і геронтопсихологія, змістом якої є поведінкові особливості осіб геронтологічного віку. У статті зосереджено увагу на тому, щчо особи геронтологічного віку потребують особливого соиіального захисту й адаптаиіï, а також постійного медичного супроводження. Доведено, щзо робота з особами геронтологічного віку для медичного персоналу вимагає особливих професійних компетенцій.

Ключові слова: компоненти, професійна компетентність, майбутні медичні сестри, геронтологія, геронтологічний вік, особи геронтологічного віку.
\end{abstract}

Oksana BUTS, orcid.org/0000-0002-5868-3612 Postgraduate at the Department of Theory and Methods of Physical Culture and Sports Zaporizhia National University (Zaporozhye, Ukraine) butsoksana1012@gmail.com

\section{COMPONENTS OF FORMATION OF PROFESSIONAL COMPETENCE OF FUTURE NURSES TO WORK WITH PERSONS OF GERONTOLOGICAL AGE}

The article substantiates the urgency of forming of the professional competence of future medical nurses to work with persons of gerontological age is determined. There is a component change in the forming of the professional competence of the medical nurses to the work with the gerontological personages, such as: personal, motivational, processual and educational components. Personal, revealed as a set of important for the professional activity of a nurse personal qualities necessary to work with a particularly vulnerable category of patients of gerontological age (ability to manage their own emotions, observation, responsibility, adequate self-esteem, empathy, self-criticism, balance, goodwill, self-control, the desire for self-improvement and self-education). Motivational, defined as a set of values, moral attitudes and social expectations, emotional and volitional complex is necessary to work with people of gerontological age. Procedural, singled out as a set of professional skills that allow carry out professional activities when working with people of gerontological age. Cognitive, revealed as the presence of professional medical knowledge and skills to work with people of gerontological age and the ability to apply them; ability to timely, qualitatively and comprehensively analyze, classify and systematize professional knowledge of gerontology, including features of prevention and treatment in the elderly, heroin hygiene, which focuses on general and special hygiene of the elderly, and gerontopsychology, the content of which is the behavioral characteristics of gerontologists. The article focuses on the fact that people of gerontological age need special social protection and adaptation, as well as constant medical support. It s proved that working with people of gerontological age for medical staff requires special professional competencies.

Key words: components, professional competence, future nurses, gerontology, gerontological age, persons of gerontological age. 
Постановка проблеми. Зі збільшенням тривалості життя зростає і кількість осіб геронтологічного віку із хронічними та психічними хворобами. Прогресія наслідків хронічних і психічних патологій робить зазначених осіб майже беззахисними у суспільстві. Вони потребують особливого соціального захисту й адаптації, а також зазвичай постійного медичного супроводження. Робота 3 особами геронтологічного віку для медичного персоналу вимагає особливих професійних компетенцій. Найбільше навантаження припадає на молодший медичний персонал, а саме медичних сестер, тому під час їх фахової підготовки виникає потреба у формуванні професійної компетентності до роботи з особами геронтологічного віку.

Мета статті - провести аналіз змісту професійної компетентності майбутніх медичних сестер до роботи з особами геронтологічного віку.

Виклад основного матеріалу. Однією з актуальних проблем розвитку педагогічної теорії та практики є вдосконалення медичної освіти з позиції професійної компетентності. Погоджуємося 3 Л. В. Лимаром, котрий зазначає, що «реформування системи охорони здоров'я та медичної освіти в Україні зумовило необхідність розробки нових критеріїв оцінювання якості роботи медиків і їхнього професіоналізму. Якщо за попередньою системою якість роботи фахівця й отримання ним кваліфікації засвідчувалося наявністю у нього певних знань та умінь, то нині якісною характеристикою фахівця є сформованість у нього професійної компетентності, що відображено у застосуванні компетентнісного підходу, передбаченого системою медичної освіти (Лимар, 2019: 67).

Саме компетентність, на думку вітчизняних науковців А. І. Могильник, Н. М. Адамчук, О. Ю. Бодулєва, визначається як «володіння людиною відповідною компетенцією, яка включає іiі особистісне ставлення до неї та предмета діяльності, розуміння відповідальності за свої дії» (Могильник, 2021: 173). У межах компетенції, як засвідчує Г. І. Кліщ, «студенти мають оволодіти базовими поняттями структури та функцій організму, здоров'я і хвороби, фазовості перебігу патологічного процесу, а також особливостями людської психіки у нормі та при патології, розуміння людини як соціальної істоти та впливу на неї зовнішніх факторів (суспільних, природних), етичних принципів медицини, мати системний спосіб мислення і структурований підхід до вирішення медичних проблем» (Кліщ, 2013: 2).

Професійна компетентність майбутніх медичних сестер забезпечується сформованістю іiі складників. О. М. Ткачук виділяє такі компо- ненти професійної компетентності: «професійно важливі якості, готовність до визначеного виду діяльності, професійну культуру, професійні здібності (когнітивний, діяльнісний, мотиваційно-ціннісний, особистісний компоненти)» (Ткачук, 2018: 610). М. Р. Демянчук - мотиваційноціннісний, теоретично-когнітивний, практичнофункціональний, особистісно-розвивальний (Демянчук, 2014: 7).

Погоджуємося із вітчизняними дослідниками стосовно того, що, адаптувавши структуру М. Волошиної та Л. Лимар, можна виділити такі компоненти - підвиди професійної компетентності: «когнітивну (медичні знання), операційну (прийняття лікарем рішень), мотиваційну (мотивацію лікаря до медичної діяльності), технологічну (проведення діагностичних і лікувальних процедур, способи організації діяльності та взаємодії 3 іншими відділеннями при лікуванні), етичну (відповідність поведінки лікаря базовим етичним принципам, прийнятим у медичному товаристві країни), соціальну (особливості взаємодії лікаря у медичному середовищі з іншими його учасниками відповідно до соціальних норм i стандартів) і поведінкову (особливості поведінки у складних ситуаціях, стратегії взаємодії, особливості емоційної саморегуляції та самоконтролю фахівця) складові частини» (Лимар, 2019: 81).

Українські дослідники I. О. Крицький, П. В. Гощинський, Т. І. Крицький, I. М. Горішній серед розмаїття структурних компонентів професійної компетентності визначають комплекс ключових: «інформаційні, які визначають способи сприйняття, зберігання i передачі інформації; проектувальні, що відображають способи визначення цілей, ресурсів, дій і термінів; аналітичні, які включають порівняння, класифікацію, абстрагування, прогнозування, систематизацію і конкретизацію; комунікативні, за допомогою котрих здійснюється передача інформації, визначається взаємодія, спілкування; соціальні (соціально-професійна позиція і ролі, які виконує фахівець у медичній галузі)» (Крицький, 2018: 3). Подібну думку розділяє Г. Г. Марараш, виокремлюючи професійно-особистісну компетентність медичної сестри як структурний складник загальної професійної компетентності, що поєднує у собі «комунікативний, особистісно-поведінковий і мотиваційний компоненти» (Марараш, 2020: 3).

Отже, на основі аналізу науково-педагогічних думок виокремлюємо такі складники професійної компетентності майбутніх медичних сестер у роботі з особами геронтологічного віку: особистісний, мотиваційний, прочесуальний, пізнавальний. 
Проаналізуємо кожен із них більш детально. Особистісний компонент, як зазначає О. М. Ткачук, - це «сукупність індивідуально-особистісних якостей і здібностей, важливих для майбутнього фахівця сестринської справи до організації роботи та сучасного фахівця-медика загалом» (Ткачук, 2018: 610). Ïї підтримують I. М. Мельничук, Л. В. Назаренко, котрі впевнені, що особистісний компонент професійної компетентності визначається «сформованістю сукупності особистісних характеристик медичної сестри, які впливатимуть на ефективність іiі діяльності за фахом. Складовими частинами цього компонента $€$ : реалізація потреби професійного становлення i самовдосконалення шляхом опанування програмового та позапрограмового навчального матеріалу й набуття професійних знань, умінь і навичок; визначення професійних ідеалів для наслідування; прагнення до професійного самовдосконалення на основі опанування необхідних умінь і навичок для успішної діяльності; належна самооцінка (загальноосвітня та професійна); чіткі ціннісні орієнтації та професійна мета. Особистісний компонент професійної компетентності медичних сестер потребує сформованості таких якостей особистості майбутнього медичного працівника середньої ланки, як спостережливість, відповідальність, співпереживання, врівноваженість, доброзичливість, толерантність, емпатійність. Цей компонент дає змогу проявляти та відображати внутрішній світ людини, розкривати сутність особистості та формувати чіткі принципи, цінності життя та світосприйняття, розкривати ставлення студента до різних життєвих і фахових ситуацій і поведінку медичної сестри у вирішенні складних професійних завдань. Цей компонент чітко окреслює особисте ставлення медичної сестри до пацієнта і його родини, до співробітників, керівників і підлеглих, формує низку комунікативних принципів продуктивної співпраці, дає можливість налагодження оптимальних професійних взаємин» (Мельничук, 2014: 4). М. Р. Демянчук показники сформованості особистісного компонента вбачає у «здатності студентів медичного коледжу до професійної рефлексії з метою визначення основних віх (акме) професійного зростання; результативність самоосвітньої діяльності; розширення професійного світогляду на основі ознайомлення із сучасними тенденціями розвитку медичної галузі та, зокрема, сестринської справи» (Демянчук, 2014: 14). В. М. Вронська впевнена, що особистісний компонент включає природне «вміння заспокоїти, створити доброзичливу атмосферу, доступно пояснити безпеч- ність, потрібність і нешкідливість виконуваних процедур, спілкуватися з людиною відповідно до iii характеру та віку, потребує певного рівня засвоєння психотерапевтичних навичок» (Вронська, 2019: 4). Саме відображення особистісних значущих морально-етичних якостей, зазначених у працях О. І. Васюти, слід включити до особистісного компоненту, а саме: «емпатійність (здатність до співчуття, співпереживання, відчуття настрою людини, розуміння іiі внутрішнього світу); делікатність, тактовність, уважність до клієнта (звернення уваги на настрій клієнта, його самопочуття, дотримання принципу «не зашкодь»); терпимість (повагу до інтересів, переконань, ідеалів, потреб, звичок інших людей, сприймання людини такою, якою вона $\epsilon$, з ії правом на обраний спосіб життя); витримку і терплячість (контроль над власними емоціями на виклики роздратованості, агресивності); високу духовну культуру й моральність, етичну поведінку, гуманність, милосердя, чуйність, безкорисливість (спрямованість на інтереси, потреби та захист людської гідності клієнта, бажання допомогти, симпатію до інших); чесність (правдивість у поясненні становища клієнта, можливостей вирішення його проблем, можливих труднощів); об'єктивність і справедливість (рівне ставлення до клієнта, незважаючи на власні симпатії, адекватне оцінювання його проблем); моральну чистоту у професійних справах, конфіденційність (уміння зберігати таємницю, якщо вона не несе загрозу іншим людям); порядність, відповідальність (моральну відповідальність за свою поведінку і наслідки власних дій), емоційно-позитивне ставлення до людей: доброзичливість, доброту, любов до людей, оптимізм (уміння сприймати людину як самоцінність, формувати позитивні почуття до неї, вселяти надію на краще)» (Васюта, 2010: 122).

У рамках когнітивного або пізнавального компоненту О. I. Васюта визначає наявність професійних знань, таких як «теоретичні (із психології, педагогіки, соціології, медицини, права, геронтології та ін.) та практичні (володіння технологіями соціальної роботи), уміння застосовувати теоретичні знання на практиці, навички роботи 3 різними категоріями клієнтів, що знаходяться в різних умовах і ситуаціях; організаторсько-комунікативні здібності: уміння швидко встановлювати контакт із людьми, виявляти їх установки, очікування; атрактивність (привабливість особистості, уміння вислухати клієнта та спрямувати бесіду в конструктивне русло); уміння викликати симпатію і довіру співрозмовника та створювати сприятливу атмосферу у взаєминах із ним; 
красномовство (уміння впливати і переконувати)» (Васюта, 2010: 122). Таку думку розділяє й О. М. Ткачук, котра наголошує на тому, що «когнітивний компонент - сукупність знань, на основі яких формується професійна компетентність із проекцією на майбутню професійну діяльність» (Ткачук, 2018: 610). М. Р. Демянчук зазначає, що сформованість теоретично-когнітивного компонента не можлива без глибоких, міцних, системних, різнопланових знань (спеціальних із медсестринства, психолого-педагогічних)» і «складно говорити про високий рівень кваліфікації та підготовленості студентів до роботи за фахом. Тож структуру теоретично-когнітивного компонента можна розглядати як поліморфну, інтеграційну, у якій поєднуються знання теорії сестринської справи, основ професійної комунікації, специфіки виконання професійних функцій залежно від психологічних особливостей і вікового цензу пацієнтів» (Демянчук, 2014: 14). О. Є. Антонова, 3. П. Шарлович у пізнавальній складовій частині говорять про гностичні вміння, що передбачають «здатність аналізувати психолого-педагогічні літературні та інші інформативні джерела та застосовувати їх на практиці; вивчати й аналізувати сучасні медсестринські та психолого-педагогічні концепції, теорії та моделі сприйняття людських потреб, орієнтованих на людину, а не на хворобу; формувати провідні цілі процесу навчання й інформування населення у зв'язку із потребами суспільства, практичними й індивідуальними потребами здорових і хворих пацієнтів; аналіз знань, умінь і навичок пацієнта та його родини, які необхідні для само- та взаємодогляду; враховувати індивідуальні особливості зміни психіки пацієнта та сприйняття ним навколишнього середовища в умовах хвороби; враховувати особливості взаємин пацієнта і його родини до і під час появи хвороби; психологічно впливати на пацієнта задля покращення його стану; оцінити рівень інтелектуального розвитку пацієнтів до початку навчання і внести корективи у методику подачі інформації; спонукати пацієнтів до інтерпретації (пояснення) своїх вчинків у зв'язку із хворобою та зміни поведінки задля одужання; аналізувати педагогічні ситуації упродовж навчання пацієнта, шукати шляхи їх розв'язання й об'єктивно оцінювати отримані результати; можливість оперативно знаходити рішення у запрограмованих і непередбачуваних педагогічних ситуаціях у навчальновиховному процесі» (Антонова, 2015: 12).

Основною ознакою процесуального або практично-функціонального компонента, за М. Р. Демянчук, $€$ «вміння використовувати знання
3 фахових дисциплін у процесі виконання роботи за фахом у квазіпрофесійних ситуаціях; вміння організовувати оптимальну професійну взаємодію у змодельованих ситуаціях; вміння інтегрувати результати професійної підготовки на практиці» (Демянчук, 2014: 14). Також у рамках процесуального компоненту можна розглядати, як засвідчують О. С. Антонова, 3. П. Шарлович, «вміння встановлювати доцільні стосунки зі здоровим контингентом населення, пацієнтами та членами їхньої родини; визначати за допомогою комунікації, що найбільше обтяжує пацієнта у цей момент, і спробувати у межах своєї компетенції скоригувати психоемоційні відхилення; спрямовувати та контролювати свої емоції, почуття та поведінку під час побудови стосунків і спілкування із пацієнтами та членами їхньої родини; стимулювати пацієнтів до власного вдосконалення самодогляду як компонента незалежності та необхідної умови у задоволенні потреб задля швидкого одужання; навчати пацієнтів самостійно формулювати проблеми i шукати шляхи їх вирішення, узгоджуючи із сімейною медичною сестрою; допомагати родичам пацієнтів усвідомити значущість їхньої фізичної, психологічної та комунікативної підтримки у пошуку шляхів до одужання члена їх сім'ї» (Антонова, 2015: 12). Процесуальний компонент, як визначає О. М. Ткачук, - це «сукупність умінь і навичок використовувати професійні знання для практичного вирішення професійних завдань» (Ткачук, 2018: 610). Не буде зайвим, на думку О. С. Антонової, 3. П. Шарлович, включити до процесуального компоненту проектувальні вміння, що «забезпечать можливість проектувати форми та методи медсестринського дослідження пацієнта і визначення стану його здоров'я; встановлювати проблеми пацієнта та формулювати медсестринські діагнози; складати разом із пацієнтом і членами його родини план медсестринських втручань; проектувати власну діяльність за встановленою короткотерміновою та довготерміновою метою; переглядати план медсестринських втручань, установлених під час етапу планування, 3 метою досягнення очікуваного результату; передбачення можливих труднощів, пов'язаних із конкретними сестринськими діями 3 метою своєчасного попередження; визначення і забезпечення необхідними інформаційними ресурсами; встановити мету, мотиваційні пріоритети навчання пацієнта для максимального забезпечення його потреб в отриманні знань; моделювати зміст інформації з індивідуального навчання та способи ії подання пацієнтам або членам його родини (розповідь, бесіда, диспут, лекція, приклад, мультимедійна 
презентація, демонстрація відеороликів, випуск санбюлетнів і брошур); моделювати методи виховання пацієнта, спрямовані на оволодіння знаннями, уміннями, навичками: методи привчання (практичні методи: тренування, доручення, гра, праця); моделювання додаткових методів, спрямованих на виховання дисциплінованості паці-

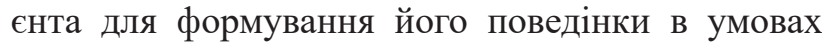
хвороби з метою створення повноцінної життєдіяльності: методи заохочення, покарання як виховний стрижень усвідомлення залежності стану здоров'я від особистого ставлення до себе» (Антонова, 2015: 1), а також конструктивні вміння, які «допоможуть встановити всі наявні або потенційні відхилення від комфортного гармонійного стану контингенту населення сімейної дільниці; реалізувати поставлені цілі, завдання, план для впровадження етапів медсестринського процесу; підібрати методи, форми та прийоми педагогічного впливу, взаємодії залежно від індивідуальних особливостей пацієнта, стимулювати його на самовдосконалення; передавати пацієнтам ініціативу у доборі змісту, форм, методів навчання та виховання; навчити пацієнтів виділяти головні напрямки у своїй життєдіяльності задля відновлення здоров'я. Крім того, конструктивні вміння забезпечать об’єктивну оцінку сімейною медичною сестрою ефективності виконаного нею медсестринського процесу і сприятимуть конструктивному та професійному внесенню коректив у план навчання пацієнта та його родини» (Антонова, 2015: 12), й обов'язково організаторські вміння, що «сприятимуть оволодінню пацієнтом і його родиною навичками само- та взаємодогляду; організовувати умови для самоосвіти пацієнтів і їхніх родин сімейної дільниці, опираючись на план навчання елементам само- та взаємодогляду організовувати умови для самоосвіти населення сімейної дільниці, з питань обізнаності елементів здорового способу життя; підготовки обладнання, необхідного для певних видів навчальної діяльності; залучати родину пацієнта до активної участі в одужанні члена її сім'ї; допоможуть пацієнтам так організувати свою життєдіяльність, щоб вона забезпечувала збереження здоров'я, а у разі хвороби сприятимуть швидкому одужанню; спонукатимуть накопиченню здоровим населенням і хворими пацієнтами корисних звичок, здорової поведінки, активності та відповідальності за власне здоров'я; вчитимуть населення сімейної дільниці способів організації рухової активності, загартовування, раціонального харчування, психічної саморегуляції, побудови міцних сімейних стосунків, активного довголіття як основи фор- мування здорового способу життя і профілактики захворювань» (Антонова, 2015: 12).

Мотиваційно-ціннісний компонент, на думку О. М. Ткачук, - це «сукупність мотивів, що спонукає до комплексного вивчення дисциплін як необхідних у професійній підготовці і майбутній практичній діяльності; мотиви, які спонукають до організації діяльності» (Ткачук, 2018: 610). М.Р. Демянчук у системі професійної підготовки майбутніх молодших спеціалістів сестринської справи вбачає основними показниками сформованості мотиваційноціннісного компонента: «вмотивованість студентів до професійного становлення і зростання у процесі навчання у медичному коледжі; усвідомлення потреби у високому рівні професійної компетентності як актуальної цінності на сучасному етапі розвитку сфери охорони здоров'я; зростаючий інтерес до оновлення різних аспектів професійної підготовки у медичному коледжі, що відповідають сучасним вимогам до молодших спеціалістів сестринської справи. Таким чином, урахування визначених показників мотиваційно-ціннісного компонента професійної компетентності сприятиме цілеспрямованій мотивації до навчання та формуванню ціннісних орієнтирів студентів медичних коледжів» (Демянчук, 2014: 14). О. І. Васюта у мотиваційноціннісному компоненті визначає доцільність професійно-важливих психологічних якостей, зокрема таких як«психічні: особливості психічних процесів (пам'яті, мислення, сприймання, відчуття, уяви); увага, як стан свідомості й умова виконання діяльності; психічні стани (працездатність, енергійність, ініціативність, стресостійкість, низький рівень тривожності); емоційно-вольові прояви (стриманість, наполегливість, послідовність, імпульсивність; інтелектуальні: соціальний інтелект (здатність аналізувати стани інших людей, передбачати розвиток подій); творче мислення (здатність приймати нестандартні рішення, діяти у невизначених ситуаціях); аналітичність, реалістичність, інтуїтивність, прогностичність, критичність, гнучкість мислення; ерудиція та кругозір; достатній освітній рівень; професійна самосвідомість: самоконтроль, самокритичність, адекватна самооцінка, прагнення до самовдосконалення й самоосвіти, самонавіюваність, уміння керувати власними емоціями та поведінкою, змінювати власні стани» (Васюта, 2010: 122).

Погоджуємося із вітчизняними науковцями та розкриваємо зміст складників професійної компетентності майбутніх медичних сестер із урахуванням особливостей у роботі з особами геронтологічного віку: особистісного, мотиваиійного, прочесуального, пізнавального. Отже, 
особистісний - сукупність важливих для професійної діяльності медичної сестри особистісних якостей, необхідних для роботи з особливо-вразливою категорією пацієнтів особами геронтологічного віку (спостережливість, відповідальність, співпереживання, врівноваженість, доброзичливість, толерантність, емпатійність). Мотиваційний - сукупність ціннісних орієнтацій, моральних установок і соціальних очікувань, емоційно-вольовий комплекс, необхідний для роботи з особами геронтологічного віку. Процесуальний - комплекс фахових умінь, що дозволяють здійснювати професійну діяльність у роботі з особами геронтологічного віку. Пізнавальний - розкривається як наявність професійних медичних знань та умінь про роботі з особами геронтологічного віку і здатність застосовувати їх; уміння вчасно, якісно та всебічно аналізувати, класифікувати і систематизувати професійні знання з геронтології.

Висновки. Внаслідок аналізу змісту готовності майбутніх медичних сестер до роботи $з$ особами геронтологічного віку визначено чотири основні компоненти: особистісний, мотиваційний, процесуальний, пізнавальний. Перспективи подальших досліджень полягають у грунтовному аналізі методів і засобів навчання, які би мали позитивний вплив на готовність майбутніх медичних сестер до роботи з особами геронтологічного віку.

\section{СПИСОК ВИКОРИСТАНИХ ДЖЕРЕЛ}

1. Антонова О. Є., Шарлович 3. П. Професійно-педагогічна компетентність медичних сестер сімейної медицини як складова їх професійної компетентності. Проблеми освіти. 2015. Вип. 85. С. 9-14.

2. Васюта О. I. Професійне становлення фахівця із соціальної роботи. Вісник Чернігівського національного педагогічного університету імені Т. Г. Шевченка. 2010. Серія «Педагогічні науки». С. 122-125.

3. Вронська В. М. Особливості психологічної компетентності медичної сестри дошкільного навчального закладу. Психологія реальність та перспективи. Вип. 11. 2019. URL: https://www.researchgate.net/publication/337072196_OSOBLIVOSTI_ PSIHOLOGICNOI KOMPETENTNOSTI MEDICNOI SESTRI DOSKILNOGO NAVCALNOGO ZAKLADU.

4. Демянчук М. Р. Критерії, компоненти, рівні і стан сформованості основ професійної компетентності майбутніх бакалаврів медсестринської справи. Професійна освіта: проблеми та перспективи. 2014. Вип. 7. С. $12-17$.

5. Кліщ Г. І. Професійна компетентність як мета підготовки сучасних лікарів у медичних університетах Австрії. Медична освіта. Вип. 4. 2013. URL: https://doi.org/10.11603/me.v0i4.1063.

6. Крицький I. О., Гощинський П. В., Крицький Т. І., Горішній I. М. Формування професійної компетентності майбутнього лікаря на прикладі студентів медичного факультету ТДМУ. Медична освіта. Bип. 9. 2018. URL: https://www.researchgate.net/publication/327842721 FORMUVANNA PROFESIJNOI KOMPETENTNOSTI MAJBUTNOGO_LIKARA_NA_PRIKLADI_STUDENTIV_MEDICNOGO_FAKULTETU_TDMU.

7. Марараш Г. Г. Характеристика професійно-особистісної компететності медичнйх сестер. Медична освіта. Вип. 2 (14). 2020. URL: https://art-of-medicine.ifnmu.edu.ua/index.php/aom/article/view/502.

8. Мельничук I. М., Назаренко Л. В. Зміст та структура професійної компетентності майбутніх медичних сестер. URL: https://ojs.tdmu.edu.ua/index.php/nursing/article/download/5133/4735.

9. Могильник А. І., Адамчук Н. М., Бодулєв О. Ю. Особливості вищої медичної освіти України в аспекті безперервного професійного розвитку. Реалї̈ проблеми та перспективи вищої медичної освіти. URL: http://elib.umsa.edu.ua/bitstream/umsa/16031/1/Mogilnik_Osoblivosti.pdf.

10. Лимар Л. В. Зміст і складові професійної компетентності сімейного лікаря: психологічний аспект. Вісник післядипломної освіти. Соціальні та поведінкові науки. 2019. Вип. 8. C. 67-83. URL: http://nbuv.gov.ua/UJRN/vispdoso_2019_8_8.

11. Ткачук О. М. Професійна компетентність майбутніх фахівців сестринської справи до організації первинної профілактики віл-інфекції серед студентської молоді. Молодий вчений. Вип. 10 (62). 2018. С. 610.

\section{REFERENCES}

1. Antonova O. I., Sharlovych Z. P. (2015) Profesiino-pedahohichna kompetentnist medychnykh sester simeinoi medytsyny yak skladova yikh profesiinoi kompetentnosti [Professional and pedagogical competence of family medicine nurses as a component of their professional competence]. Problems of education. Vol. 85. P. 9-14 [in Ukrainian].

2. Vasiuta O. I. (2010) Profesiine stanovlennia fakhivtsia iz sotsialnoi roboty [Professional development of a social work specialist]. Bulletin of the T. H. Shevchenko National University "Chernihiv Colehium”. P. 122-125. [in Ukrainian].

3. Vronska V. M. (2019) Osoblyvosti psykholohichnoi kompetentnosti medychnoi sestry doshkilnoho navchalnoho zakladu [Features of psychological competence of a nurse of a preschool educational institution]. Psychology: reality and perspectives. Vol. 11 URL: https://www.researchgate.net/publication/337072196 OSOBLIVOSTI PSIHOLOGICNOI KOMPETENTNOSTI MEDICNOI SESTRI DOSKILNOGO NAVCALNOGO ZĀKLADU [in Ukrainian].

4. Demianchuk M. R. (2014) Kryterii, komponenty, rivni i stan sformovanosti osnov profesiinoi kompetentnosti maibutnikh bakalavriv medsestrynskoi spravy [Criteria, components, levels and state of formation of bases of professional competence of future bachelors of nursing]. Professional education: problems ta perspectives. Vol. 7. P. 12-17 [in Ukrainian].

5. Klishch H. I. (2013) Profesiina kompetentnist yak meta pidhotovky suchasnykh likariv u medychnykh universytetakh Avstrii [Professional competence as a goal of training modern doctors in Austrian medical universities]. Medical education. Vol. 4. URL: https://doi.org/10.11603/me.v0i4.1063 [in Ukrainian] 
6. Krytskyi I. O., Hoshchynskyi P. V., Krytskyi T. I., Horishnii I. M. Formuvannia profesiinoi kompetentnosti maibutnoho likaria na prykladi studentiv medychnoho fakultetu TDMU [Formation of professional competence of the future doctor on the example of students of the medical faculty of TSMU]. Medical education. Vol. 9. 2018. URL: https://www.researchgate. net/publication/327842721_FORMUVANNA_PROFESIJNOI_KOMPETENTNOSTI_MAJBUTNOGO_LIKARA_NA_ PRIKLADI_STUDENTIV_MEDICNOGO_FAKULTETU_TDMU [in Ukrainian].

7. Mararash H. H. (2020) Kharakterystyka profesiino-osobystisnoi kompetetnosti medychnykh sester [Characteristics of professional and personal competence of nurses]. Medical education. Vol. 2 (14). URL: https://art-of-medicine.ifnmu.edu.ua/ index.php/aom/article/view/502 [in Ukrainian].

8. Melnychuk I. M., Nazarenko L. V. Zmist ta struktura profesiinoi kompetentnosti maibutnikh medychnykh sester [Content and structure of professional competence of future nurses]. URL: https://ojs.tdmu.edu.ua/index.php/nursing/article/ download/5133/4735 [in Ukrainian].

9. Mohylnyk A. I., Adamchuk N. M., Boduliev O. I. Osoblyvosti vyshchoi medychnoi osvity Ukrainy v aspekti bezperervnoho profesiinoho rozvytku [Features of higher medical education in Ukraine in terms of continuing professional development]. Realities of the problem and prospects of higher medical education. URL: http://elib.umsa.edu.ua/bitstream/ umsa/16031/1/Mogilnik_Osoblivosti.pdf [in Ukrainian].

10. Lymar L. V. (2019) Zmist i skladovi profesiinoi kompetentnosti simeinoho likaria: psykholohichnyi aspekt [Content and components of professional competence of a family doctor: psychological aspect]. Bulletin of postgraduate education. Social and behavioral sciences. Vol. 8. P. 67-83. URL: http://nbuv.gov.ua/UJRN/vispdoso_2019_8_8 [in Ukrainian].

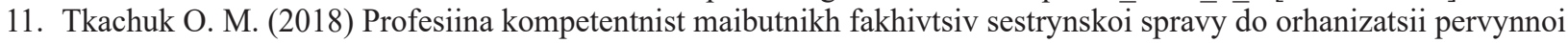
profilaktyky vil-infektsii sered studentskoi molodi [Professional competence of future nursing specialists in the organization of primary prevention of HIV infection among student youth]. Young scientists. Vol. 10 (62). P. 610 [in Ukrainian]. 